\title{
Remainder Imunisasi Pada Sistem Informasi Posyandu untuk Memantau Kelengkapan Imunisasi Rutin Anak di Masa Pandemi Covid-19
}

\author{
Dini Suhartini ${ }^{1}$, Yunita Rahma ${ }^{2}$, Lusi Agus Setiani ${ }^{3}$ \\ ${ }^{1}$ Manajemen Informatika Sekolah Vokasi Universitas Pakuan, \\ ${ }^{2,}$ Teknologi Komputer Sekolah Vokasi Universitas Pakuan, \\ ${ }^{3}$ Farmasi Fakultas MIPA Universitas Pakuan \\ ${ }^{1,2,3}$ Pakuan PO BOX 452 Ciheuleut, Bogor Timur, Bogor, Indonesia \\ e-mail: ${ }^{1}$ dini.suhartini@ unpak.ac.id, ${ }^{2}$ yunita.rahma@ unpak.ac.id, ${ }^{3}$ lusi.setiani@unpak.ac.id
}

\begin{abstract}
Abstrak
Pandemi Covid-19 membuat banyak orang tua telat bahkan tidak memberikan imunisasi rutin kepada anaknya karena takut akan terpapar virus jika mendatangi tempat pemberian imunisasi. Sesuai surat edaran Kemenkes 24 Maret 2020, pemerintah mewajibkan agar seluruh pelayanan kesehatan seperti Puskesmas dan Posyandu melaksanakan kegiatan pemberian imunisai sesuai dengan ketentuan dan proteksi kesehatan.Untuk membantu bidan dan kader posyandu dalam memantau imunisasi rutin anak,dibuatkanlah remainder imunisasi pada Sistem Informasi Posyandu. Metode Forward Chainning digunakan sebagai pelacak imunisasi dan Best First Search sebagai pencari penentuan keputusan untuk memunculkan remainder imunisasi secara otomatis. Rule imunisasi yang digunakan untuk pelacakan sesuai dengan aturan imunisasi rutin anak yang dikeluarkan oleh IDAI dan konsultasi dengan bidan sebagai pakar. Tanggal lahir anak digunakan sebagai acuan pelacakan sesuai dengan rule imunisasi rutin anak untuk memunculkan remainder imunisasi anak. Ujicoba yang dilakukan pada Sistem menggunakan blackbox testing dengan hasil semua fitur berfungsi dengan baik. Remainder imunisasi anak dapat membantu bidan dan kader untuk memantau imunisasi rutin anak di Posyandu khususnya saat pandemi Covid-19.
\end{abstract}

Kata kunci: Remainder, Imunisasi, Forward Chainning, Covid 19, Posyandu

\begin{abstract}
The Covid-19 pandemic has made many parents late even not giving routine immunizations to their children for fear of being exposed to the virus if they come to the immunization site. According to the Ministry of Health circular letter March 24, 2020, the government requires that all health services such as Puskesmas and Posyandu carry out immunization activities in accordance with health provisions and protection. To assist midwives and posyandu cadres in monitoring routine child immunizations, immunization remainder are made in the Posyandu Information System. The Forward Chainning method is used as an immunization tracker and the Best First Search as a decision-making search to bring up the immunization remainder automatically. The immunization rules used for tracking are in accordance with the routine immunization rules for children issued by IDAI and consultation with midwives as experts. The child's date of birth is used as a tracking reference according to the routine child immunization rule to bring up the child immunization remainder. Tests carried out on the system use blackbox testing with the results of all features functioning properly. Child immunization remainder can help midwives and cadres to monitor routine immunizations for children at Posyandu, especially during the Covid-19 pandemic.
\end{abstract}

Keywords: Remainder, Immunization, Forward Chainning, Covid 19, Posyandu. 


\section{Pendahuluan}

Dunia digemparkan dengan adanya infeksi pneumonia berat yang melanda Cina tepatnya di kota Wuhan, propinsi Hubei, hal tersebut dilaporkan Cina kepada World Health Organization (WHO) pada akhir tahun 2019. Infeksi ini setelah diteliti lebih mendalam ternyata disebabkan oleh sebuah virus yang disebut dengan Novel Corona Virus 19 atau biasa disebut dengan Covid 19. Menyebarnya virus corona baru dengan cepat antar manusia menjadikan pandemik yang menyebabkan infeksi covid 19 [1].

Selama pandemi covid 19, banyak orang tua yang merasa cemas untuk mengajak anaknya ke tempat pelayanan kesehatan seperti Posyandu, Puskesmas, bahkan Rumah Sakit sekalipun untuk melakukan imunisasi rutin. Hal ini mengakibatkan terjadinya pengurangan kuantitas kunjungan orang tua ke pelayanan gizi dan KIA, sehingga berpotensi menimbulkan masalah gizi dan kesehatan baru [2]. Salah satu usaha untuk menaikkan imunitas tubuh sampai batas kadar protektif tercapai bisa dilakukan dengan imunisasi, karena dengan Melaksanakan Imunisasi salah satu usaha yang dapat mengakibatkan atau meningkatkan kekebalan tubuh seseorang terhadap suatu jenis penyakit tertentu dan dilaksanakan menggunakan jadwal imunisasi yang ditentukan [3] [4]. Selama pandemi berlangsung, pemerintah memutuskan agar anak terlindungi dari PD3I, pelaksanaan imunisasi harus tetap diusahakan lengkap dan dilaksanakan menggunakan jadwal yang sudah ditetapkan, sesuai dengan ketentuan pemerintah dalam imunisasi untuk anak yaitu imunisasi yang dilakukan secara rutin yang terdiri dari imunisasi dasar dan imunisasi lanjutan [5] [6].

Untuk memastikan anak-anak mendapatkan imunisasi yang lengkap, pemerintah meramu petunjuk teknis dalam pelayanan imunisasi saat pandemi Covid 19. Salah satunya yaitu petunjuk teknis pelayanan imunisasi yang dilakukan oleh petugas Puskesmas dan Kader Posyandu. Petugas dan kader harus melacak anak yang akan mendapatkan imunisasi rutin untuk dibuatkan jadwal janji pemberian imunisasi dan juga memberitahu orang tua anak untuk jadwal berikutnya [7]. Pencatatan data anak dan imunisasi rutin anak berikut dengan jadwalnya yang dilakukan oleh bidan Puskesmas yang ditugaskan ke Posyandu Kenanga Desa Pakansari dan kadernya masih konvensional. Data dan informasi tersebut dicatatkan kedalam buku besar kegiatan Posyandu dan buku KIA (Kesehatan Ibu dan Anak) yang dipegang oleh orantua anak. Hal tersebut mengakibatkan kesulitan dalam pelacakan dan pemantauan kelengkapan jadwal imunisasi rutin anak untuk dibuatkan jadwal janji pemberian imunisasi. Karena bidan dan kader harus melacak satu persatu data anak berikut dengan jadwalnya, mengakibatkan ketidak efektifan dalam pembuatan jadwal janji pemberian imunisasi.

Penelitian yang pernah dilakukan sebelumnya yaitu aplikasi berbasiskan android yang digunakan oleh user dan website yang digunakan oleh admin. Pada aplikasi yang digunakan user terdapat alarm imunisasi yang diatur secara manual oleh user yang kemundian akan muncul remainder imunisasi berupa notifikasi pada layar handphone. Sedangkan admin hanya dapat memantau kelengkapan imunisasi dan tubuh kembang anak melalui aplikasi website [8]. Penelitian lainnya yaitu sistem informasi pengingat jadwal imunisasi yang terdiri dari aplikasi berbasiskan android untuk user dan website untuk petugas dan admin. Pada sistem ini petugas akan menginputkan jadwal imunisasi anak selanjutnya secara manual berikut dengan jadwal Posyandu yang akan muncul di aplikasi yang dipakai user sebagai pengingat [9].

Sebuah sistem dikatakan sistem pakar jika sistem tersebut mengambil keahlian dan ilmu manusia yang kemudian didesain dan dimodelkan kemampuan tersebut kedalam komputer sehingga menghasilkan penyelesaian seperti seorang pakar [10]. Melihat permasalahan yang dihadapi oleh bidan dan kader dalam melcak dan memantau imunisasi rutin anak dan merujuk pada penelitian yang pernah dilakukan, maka solusi yang dapat diberikan yaitu sebuah sistem pakar berupa remainder imunisasi pada Sistem Informasi Posyandu. Remainder atau pengingat tersebut dapat membantu dalam melacak dan memantau imunisasi anak secara otomatis, sehingga bidan dan kader tidak harus melacak dan memantau secara konvensional satu persatu dicari.Remainder atau pengingat imunisasi dirancang sesuai dengan keilmuan pakar dokter anak yang tertuang dalam jadwal imunisasi anak 2017, dimana terdapat penyeragaman jadwal yang 
direkomendasikan IDAI (Ikatan Dokter Anak Indonesia) dengan jadwal yang ditentukan oleh Kementerian Kesehatan Republik Indonesia [11].

Memunculkan remainder ini dibuat menggunakan metode Forward Chainning untuk pelacakannya dan Best First Search untuk pencarian keputusan sehingga pelacakan imunisasi rutin anak dapat muncul secara otomatis berupa remainder pada Sistem Informasi Posyandu yang dapat dilihat oleh bidan dan kader. Metode tersebut pernah digunakan dalam penelitian sistem pakar yang diperuntukkan bagi calon dokter dalam membantu mendiagnosa gangguan pada sistem Hepatobiliaris menggunakan Forward Chainning dan Best First Search sebagai metode dalam pencarian keputusan[12]. Proses metode ini memerlukan data yang sudah disiapkan dan memakai ketentuan-ketentuan inferensi sehingga mencapai kesimpulan yang diperoleh [13]. Data driven digunakan pada pendekatan pelacakan ke depan [14]. Remainder imunisasi anak akan muncul berdasarkan data tanggal lahir anak dan imunisasi yang harus diberikan sesuai dengan jadwal imunisasi yang ditetapkan sebagai data driven.

Sistem Informasi Posyandu dibuat berbasiskan website, karena dengan perkembangan teknologi yang beracuan pada era Revolusi Industri 4.0 dan Masyarakat 5.0, hampir segala aspek kehidupan menggunakan teknologi internet. Hal tersebut diperkuat dengan hasil survey APJII (Asosiasi Penyelenggara Jasa Internet Indosesia) pada tahun 2019 sampai dengan tahun 2020 penggunaan internet di Indonesia sekitar 73,3\% [15].

\section{Metode Penelitian}

Metode penelitian yang dilakukan mengikuti kerangka pemikiran yang dibuat sesuai dengan kebutuhan penelitian.

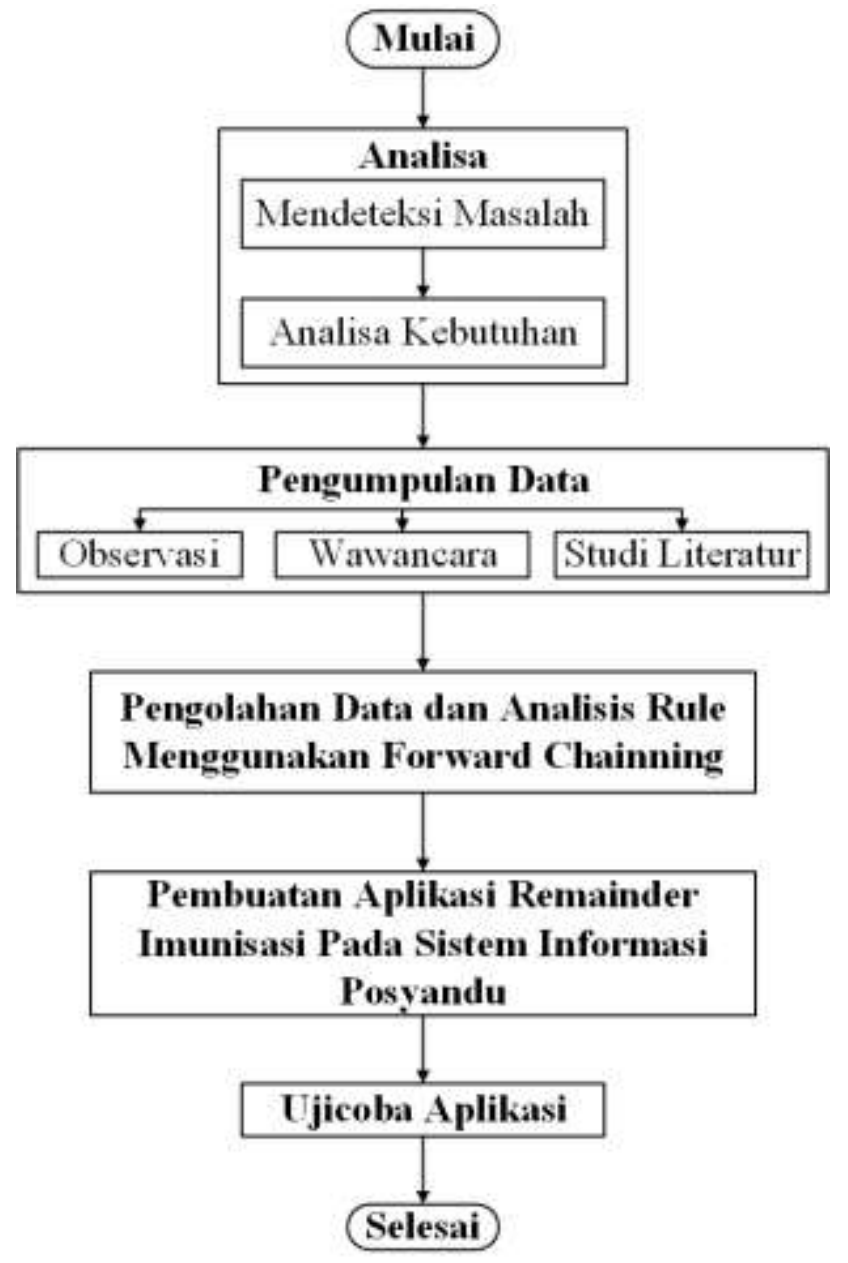

Gambar 1. Kerangka Pemikiran Penelitian 


\subsection{Analisa}

Tahap analisa merupakan tahap awal yang dilakukan dalam kegiatan penelitian yaitu :

1. Mendeteksi masalah dengan melihat kesulitan yang dihadapi oleh bidan dan kader Posyandu Kenanga Desa Pakansari dalam mencari dan memantau imunisasi rutin anak di Posyandu, khususnya saat pandemi Covid 19 dimana pemerintah sudah menentukan prosedur dalam menyelenggarakan imunisasi anak di Posyandu saat pandemi Covid 19.

2. Analisa kebutuhan dilakukan dengan menimbang dan menelaah kendala dan kesulitan yang dihadapi petugas Puskesmas dan kader Posyandu sehingga menghasilkan solusi berupa Sistem Pakar dalam bentuk remainder atau pengingat imunisasi anak pada Sistem Informasi Posyandu. Remainder tersebut akan memunculkan informasi anak-anak yang akan diimunisasi secara otomatis sesuai dengan jadwal imunisasi rutin anak.

\subsection{Pengumpulan data}

Tahap pengumpulan data dilakukan untuk mengumpulkan data sesuai dengan kebutuan dari solusi yang dihasilkan dengan melakukan tiga langkah yaitu :

1. Observasi dilakukan dengan melihat langsung ke lapangan yaitu Posyandu Kenanga, Desa Pakansari mengenai prosedur penyelenggaraan imunisasi anak saat pandemi Covid 19.

2. Wawancara dilakukan dengan bidan yang ditugaskan oleh Puskesmas setempat di Posyandu Kenanga mengenai jenis-jenis dan jadwal imunisasi rutin anak dan ketentuan dalam pemberian imunisasi anak.

3. Studi literatur dilakukan dengan mengumpulkan informasi yang dibutuhkan dalam analis is dan pembuatan aplikasi. Data yang dibutuhkan yaitu data anak Posyandu Kenanga, tabel imunisasi rutin anak, dan literatur pendukung lainnya yang berhubungan dengan metode analisis Forward Chainning.

\subsection{Pengolahan Data Dan Analisis Rule Menggunakan Forward Chainning}

Tahap pengolahan data dan analisis rule dilakukan setelah mendapatkan informasi dan data yang dibutuhkan untuk remainder imunisasi menggunakan Forward Chainning. Langkahlangkah yang dilakukan pada pengolahan data dan analisis rule :

1. Menyiapkan basis pengetahuan yang merupakan sebuah presmis informasi yang menyimpan aturan-aturan tentang suatu pengetahuan tertentu. Basis pengetahuan yang dipakai berupa fakta-fakta mengenai imunisasi yaitu jadwal imunisasi, dan ketentuan atau persyaratan imunisasi[16].

2. Mesin inferensi dapat dikatakan bagian dari komponen Sistem Pakar, dimana dapat melakukan proses memanipulasi dan mengarahkan pengetahuan berdasarkan basis pengetahuan untuk mencapai suatu kesimpulan. Tugas mesin inferensi yaitu menguji fakta dan kaidah pada basis pengetahuan ataupun memuat fakta baru sehingga dapat menghasilkan suatu keputusan sesuai dengan penalaran yang dilakukan [16].

Mesin inferensi yang digunakan untuk memunculkan remainder imunisasi anak pada Sistem Informasi Posyandu yaitu menggunakan metode Forward Chainning. Metode Forward chaining yakni metode pelacakan yang diawali dengan menyajikan gabungan data atapun fakta sehingga mengeluarkan kesimpulan akhir yang sesuai. Pelacakan maju diawali dari asumsi-asumsi atau data masukan (if) terlebih dahulu yang akhirnya menuju kesimpulan atau informasi turunan (then) yang dapat dijelaskan berikut :[17]

IF (data masukan)

THEN (kesimpulan)

Sebagai contoh pemahaman dalam kasus sistem pakar menggunakan Forward Chainning :

Rule : Jika Fakta 1 Benar

Dan Fakta 2 Benar

Dan Fakta 3 Benar

Dan Fakta 4 Benar

Maka Hasil Keputusan[14] 
3. Metode Pencarian yang digunakan dalam memunculkan remainder imunisasi anak yaitu menggunakan Best First Search. Metode ini merupaka gabungan antara Depth First Search dan Breadth First Search. Pencarian dilakukan sehingga menghasilkan suatu keputusan hasil yang sesuai dengan rule yang sudah ditentukan. Metode Best First Search dalam melakukan panduan pencarian mengaarah ke node yang tepat dimana solusi dari masalah berada [18].

\subsection{Pembuatan Aplikasi Remainder Imunisasi Pada Sistem Informasi Posyandu}

Metode yang digunakan dalam pembuatan aplikasi remainder imunisasi pada sistem informasi posyandu menggunakan metode Waterfall, yang mempunyai segenap tahapan yang berurut terdiri dari analisis kebutuhan, desain sistem, pemograman dan uji coba, penerapan program, pemeliharaan [19]. Tahap desain merupakan tahapan yang menjelaskan secara detail mengenai proses sistem yang akan dibuat, proses sistem akan berfokus pada perancangan sistem dan database. Perancangan menggunakan pendekatan UML (Unified Modeling Language) yang merupakan perancangan sistem berbasiskan objek. Menggunakan UML suatu sistem informasi siap digunakan oleh pemakai, karena dengan UML dapat menggambarkan desain sistem informasi yang akan dibuat [20]. Tahap Implementasi adalah tahap penerjemahan dari tahap desain kedalam kode-kode menggunakan bahasa pemograman yang akan dipakai. Program dibuat secara perunit yang langsung diujikan dan kemudian akan diintegrasikan dengan program unit-unit yang lain. Bahasa pemograman yang dipakai yaitu bahasa pemograman yang berbasiskan objek dan database yang sesuai. Software yang dipakai diantaranya yaitu database menggunakan $M y S q l$, pembuatan Website menggunakan Visual Studio Code.

\subsection{Ujicoba Aplikasi}

Ujicoba dilakukan untuk menguji keakuratan sistem antara input dan output pada sistem yang dibangun. Teknik yang digunakan dalam pengujian remainder imunisasi anak yaitu teknik pengujian BlackBox. Teknik pengujian ini dilakukan untuk mengetahui setiap fungsi pada setiap halaman sistem berfungsi atau tidak, dan output sesuai dengan rule yang ditentukan. Selain ujicoba blackbox juga dilakukan ujicoba kepuasan user terhadap sistem yang dibangun menggunakan kuesioner dengan skala likert. Responden ujicoba terdiri dari bidan dan kader Posyandu Kenanga.

\section{Hasil dan Pembahasan}

\subsection{Basis Pengetahuan}

Basis pengetahuan untuk membuat remainder imunisasi menggunakanfakta-fakta dan rule imunisasi rutin berdasarkan informasi dan pengalaman dari pakar yaitu bidan Puskesmas yang ditugaskan di Posyandu dan juga berlandaskan sesuai dengan IDAI 2017.

Tabel 1. Tabel Imunisasi Rutin Anak

\begin{tabular}{cl}
\hline $\begin{array}{c}\text { Kode } \\
\text { Imunisasi }\end{array}$ & \multicolumn{1}{c}{ Nama Imunisasi } \\
\hline I001 & Imunisasi HB 0 \\
\hline I002 & Imunisasi Polio 0 \\
\hline I003 & Imunisasi BCG \\
\hline I004 & Imunisasi DPT-HB-Hib 1 \\
\hline I005 & Imunisasi Polio 1 \\
\hline I006 & Imunisasi DPT-HB-Hib 2 \\
\hline I007 & Imunisasi Polio 2 \\
\hline I008 & Imunisasi DPT-HB-Hib 3 \\
\hline I009 & Imunisasi Polio 3 \\
\hline I010 & Imunisasi IPV \\
\hline
\end{tabular}




\begin{tabular}{cl}
\hline $\begin{array}{c}\text { Kode } \\
\text { Imunisasi }\end{array}$ & \multicolumn{1}{c}{ Nama Imunisasi } \\
\hline I011 & Imunisasi Campak 1 / MR 1 \\
\hline I012 & Imunisasi DPT-HB-Hib 4 \\
\hline I013 & Imunisasi Campak 2 / MR 2 \\
\hline I014 & Imunisasi Baduta lengkap \\
\hline
\end{tabular}

Tabel imunisasi rutin anak berisikan kode beserta penjelasannya yang diambil dari jadwal imunisasi anak yang dikeluarkan oleh IDAI 2017. Kode imunisasi dibuat secara berurut sesuai dengan urutan imunisasi yang terdiri dari imunisasi HB 0, Polio 0, BCG, DPT-HB-Hib 1, Polio 1, DPT-HB-Hib 2, Polio 2, DPT-HB-Hib 3, Polio 3, IPV, Campak 1 / MR 1, DPT-HB-Hib 4, Campak / MR 2. Pada kode terakhir dijelaskan bahwa Baduta (Bawah Dua Tahun) lengkap menyatakan bahwa anak sudah diimunisasi secara lengkap pada usia anak bawah usia dua tahun.

Tabel 2. Ketentuan Imunisasi Rutin Anak

\begin{tabular}{cl}
\hline $\begin{array}{c}\text { Kode } \\
\text { Ketentuan }\end{array}$ & \multicolumn{1}{c}{ Nama Ketentuan } \\
\hline K001 & umur anak antara 0-7 hari \\
\hline K002 & umur anak >=1 bulan (30 hari) \\
\hline K003 & tgl imunisasi HB 0 terisi \\
\hline K004 & interval tgl imunisasi HB 0 dengan tgl sekarang $>=28$ hari \\
\hline K005 & umur anak >=2 bulan (60 hari) \\
\hline K006 & tgl imunisasi BCG terisi \\
\hline K007 & interval tgl imunisasi BCG dengan tgl sekarang $>=28$ hari \\
\hline K008 & tgl imunisasi Polio 0 terisi \\
\hline K009 & interval tgl imunisasi Polio 0 dengan tgl sekarang $>=28$ hari \\
\hline K010 & umur anak >=3 bulan (90 hari) \\
\hline K011 & tgl imunisasi DPT-HB-Hib 1 terisi \\
\hline K012 & interval tgl imunisasi DPT-HB-Hib 1 dengan tgl sekarang $>=28$ hari \\
\hline K013 & tgl imunisasi Polio 1 terisi \\
\hline K014 & interval tgl imunisasi Polio 1 dengan tgl sekarang $>=28$ hari \\
\hline K015 & umur anak >=4 bulan (120 hari) \\
\hline K016 & tgl imunisasi DPT-HB-Hib 2 terisi \\
\hline K017 & interval tgl imunisasi DPT-HB-Hib 2 dengan tgl sekarang $>=28$ hari \\
\hline K018 & tgl imunisasi Polio 2 terisi \\
\hline K019 & interval tgl imunisasi Polio 2 dengan tgl sekarang $>=28$ hari \\
\hline K020 & tgl imunisasi DPT-HB-Hib 3 terisi \\
\hline K021 & interval tgl imunisasi DPT-HB-Hib 3 dengan tgl sekarang $>=28$ hari \\
\hline K022 & umur anak >=9 bulan (270 hari) \\
\hline K023 & umur anak >=18 bulan 540 hari) \\
\hline K024 & interval tgl imunisasi DPT-HB-Hib 3 dengan tgl sekarang $>=12$ bulan \\
(365 hari)
\end{tabular}




\begin{tabular}{cl}
\hline $\begin{array}{c}\text { Kode } \\
\text { Ketentuan }\end{array}$ & \multicolumn{1}{c}{ Nama Ketentuan } \\
\hline K026 & $\begin{array}{l}\text { interval tgl imunisasi Camapk 1 / MR 1 dengan tgl sekarang }>=6 \text { bulan } \\
(\text { 180 hari })\end{array}$ \\
\hline K027 & interval tgl imunisasi DPT-HB-Hib 4 dengan tgl sekarang >= 28 hari \\
\hline K028 & tgl imunisasi Polio 3 terisi \\
\hline K029 & tgl imunisasi IPV terisi \\
\hline K030 & tgl imunisasi DPT-HB-Hib 4 terisi \\
\hline K031 & tgl imunisasi Campak 2 / MR 2 terisi \\
\hline
\end{tabular}

Tabel Ketentuan Imunisasi Rutin Anak berisikan persyaratan atau ketentuan anak untuk mendapatkan imunisasi. Ketentuan imunisasi didapat dari jadwal imunisasi rutin anak dan konsultasi dengan pakar imunisasi yaitu bidan yang ditugaskan di Posyandu. Ketentuan imunisasi berdasarkan umur anak, tgl anak diberikan imunisasi, serta interval imunisasi sebelumnya dengan jadwal imunisasi.

\subsection{Mesin Inferensi dan Mesin Pencarian}

Tabel 3. Rule Imunisasi

\begin{tabular}{|c|c|c|}
\hline RULE & IF & THEN \\
\hline 1 & umur anak antara 0-7 hari & Imunisasi HB 0 \\
\hline 2 & umur anak >=1 bulan (30 hari) & Imunisasi Polio 0 \\
\hline \multirow{3}{*}{3} & umur anak >=1 bulan (30 hari) & \multirow{3}{*}{ Imunisasi BCG } \\
\hline & tgl imunisasi HB 0 terisi & \\
\hline & $\begin{array}{l}\text { interval tgl imunisasi HB } 0 \text { dengan tgl sekarang >= } \\
28 \text { hari }\end{array}$ & \\
\hline \multirow{3}{*}{4} & umur anak $>=2$ bulan ( 60 hari) & \multirow{3}{*}{ Imunisasi DPT-HB-Hib 1} \\
\hline & tgl imunisasi BCG terisi & \\
\hline & $\begin{array}{l}\text { interval tgl imunisasi BCG dengan tgl sekarang }>= \\
28 \text { hari }\end{array}$ & \\
\hline \multirow{3}{*}{5} & umur anak $>=2$ bulan (60 hari) & \multirow{3}{*}{ Imunisasi Polio 1} \\
\hline & tgl imunisasi Polio 0 terisi & \\
\hline & $\begin{array}{l}\text { interval tgl imunisasi Polio } 0 \text { dengan tgl sekarang } \\
>=28 \text { hari }\end{array}$ & \\
\hline \multirow{3}{*}{6} & umur anak $>=3$ bulan $(90$ hari $)$ & \multirow{3}{*}{ Imunisasi DPT-HB-Hib 2} \\
\hline & tgl imunisasi DPT-HB-Hib 1 terisi & \\
\hline & $\begin{array}{l}\text { interval tgl imunisasi DPT-HB-Hib } 1 \text { dengan tgl } \\
\text { sekarang }>=28 \text { hari }\end{array}$ & \\
\hline \multirow{3}{*}{7} & umur anak $>=3$ bulan $(90$ hari) & \multirow{3}{*}{ Imunisasi Polio 2} \\
\hline & tgl imunisasi Polio 1 terisi & \\
\hline & $\begin{array}{l}\text { interval tgl imunisasi Polio } 1 \text { dengan tgl sekarang } \\
>=28 \text { hari }\end{array}$ & \\
\hline \multirow{3}{*}{8} & umur anak $>=4$ bulan (120 hari) & \multirow{3}{*}{ Imunisasi DPT-HB-Hib 3} \\
\hline & tgl imunisasi DPT-HB-Hib 2 terisi & \\
\hline & $\begin{array}{l}\text { interval tgl imunisasi DPT-HB-Hib } 2 \text { dengan tgl } \\
\text { sekarang }>=28 \text { hari }\end{array}$ & \\
\hline \multirow{3}{*}{9} & umur anak $>=4$ bulan $(120$ hari) & \multirow{3}{*}{ Imunisasi Polio 3} \\
\hline & tgl imunisasi Polio 2 terisi & \\
\hline & $\begin{array}{l}\text { interval tgl imunisasi Polio } 2 \text { dengan tgl sekarang } \\
>=28 \text { hari }\end{array}$ & \\
\hline
\end{tabular}




\begin{tabular}{|c|c|c|}
\hline RULE & IF & THEN \\
\hline \multirow{3}{*}{10} & umur anak $>=4$ bulan (120 hari) & \multirow{3}{*}{ Imunisasi IPV } \\
\hline & tgl imunisasi DPT-HB-Hib 3 terisi & \\
\hline & $\begin{array}{l}\text { interval tgl imunisasi DPT-HB-Hib } 3 \text { dengan tgl } \\
\text { sekarang }>=28 \text { hari }\end{array}$ & \\
\hline \multirow{3}{*}{11} & umur anak $>=9$ bulan (270 hari) & \multirow{3}{*}{$\begin{array}{l}\text { Imunisasi Campak } 1 / \text { MR } \\
1\end{array}$} \\
\hline & tgl imunisasi DPT-HB-Hib 3 terisi & \\
\hline & $\begin{array}{l}\text { interval tgl imunisasi DPT-HB-Hib } 3 \text { dengan tgl } \\
\text { sekarang }>=28 \text { hari }\end{array}$ & \\
\hline \multirow{3}{*}{12} & umur anak $>=18$ bulan (540 hari) & \multirow{3}{*}{ Imunisasi DPT-HB-Hib 4} \\
\hline & tgl imunisasi DPT-HB-Hib 3 terisi & \\
\hline & $\begin{array}{l}\text { interval tgl imunisasi DPT-HB-Hib } 3 \text { dengan tgl } \\
\text { sekarang }>=12 \text { bulan ( } 365 \text { hari) }\end{array}$ & \\
\hline \multirow{4}{*}{13} & umur anak $>=18$ bulan $(540$ hari) & \multirow{4}{*}{$\begin{array}{l}\text { Imunisasi Campak } 2 \text { / MR } \\
2\end{array}$} \\
\hline & tgl imunisasi Campak 1 / MR 1 terisi & \\
\hline & $\begin{array}{l}\text { interval tgl imunisasi Camapk 1 / MR } 1 \text { dengan tgl } \\
\text { sekarang }>=6 \text { bulan ( } 180 \text { hari) }\end{array}$ & \\
\hline & $\begin{array}{l}\text { interval tgl imunisasi DPT-HB-Hib } 4 \text { dengan tgl } \\
\text { sekarang >= } 28 \text { hari }\end{array}$ & \\
\hline \multirow{13}{*}{14} & tgl imunisasi HB 0 terisi & \multirow{13}{*}{ Imunisasi Baduta lengkap } \\
\hline & tgl imunisasi BCG terisi & \\
\hline & tgl imunisasi Polio 0 terisi & \\
\hline & tgl imunisasi DPT-HB-Hib 1 terisi & \\
\hline & tgl imunisasi Polio 1 terisi & \\
\hline & tgl imunisasi DPT-HB-Hib 2 terisi & \\
\hline & tgl imunisasi Polio 2 terisi & \\
\hline & tgl imunisasi DPT-HB-Hib 3 terisi & \\
\hline & tgl imunisasi Polio 3 terisi & \\
\hline & tgl imunisasi IPV terisi & \\
\hline & tgl imunisasi Campak 1 / MR 1 terisi & \\
\hline & tgl imunisasi DPT-HB-Hib 4 terisi & \\
\hline & tgl imunisasi Campak 2 / MR 2 terisi & \\
\hline
\end{tabular}

Tabel rule Imunisasi berisikan aturan dalam mengeluarkan remainder imunisasi anak yang menggunakan metode forward chainning sebagai mesin inferensinya. Metode ini menggunakan kaidah Jika - Maka (IF - THEN) dalam pelacakan datanya. Sebagai contoh pembacaan tabel pada pelacakan remainder imunisasi rutin anak sebagai berikut :

Rule pelacakan untuk memunculkan remainder imunisasi HB 0, imunisasi Polio 0 dan imunisasi BCG

Rule 1 : Jika umur anak antara 0-7 hari Benar Maka Imunisasi HB 0

Rule 2 : Jika umur anak >=1 bulan (30 hari) Benar Maka Imunisasi Polio 0

Rule 3 : Jika umur anak >=1 bulan (30 hari) Benar

Dan tgl imunisasi HB 0 terisi Benar

Dan interval tgl imunisasi HB 0 dengan tgl sekarang $>=28$ hari Benar Maka Imunisasi BCG

Tahap selanjutnya setelah proses mesin inferensi menggunakan forward chainning yaitu melakukan pencarian menggunakan metode Best First Search. Metode ini dilakukan untuk mencari keputusan yang tepat sesuai dengan rule yang sudah ditentukan untuk mengeluarkan notifikasi remainder imunisasi rutin anak. Pohon keputusan menggambarkan alur dari pencarian rule imunisasi sampai akhirnya menghasilkan sebuah keputusan. 


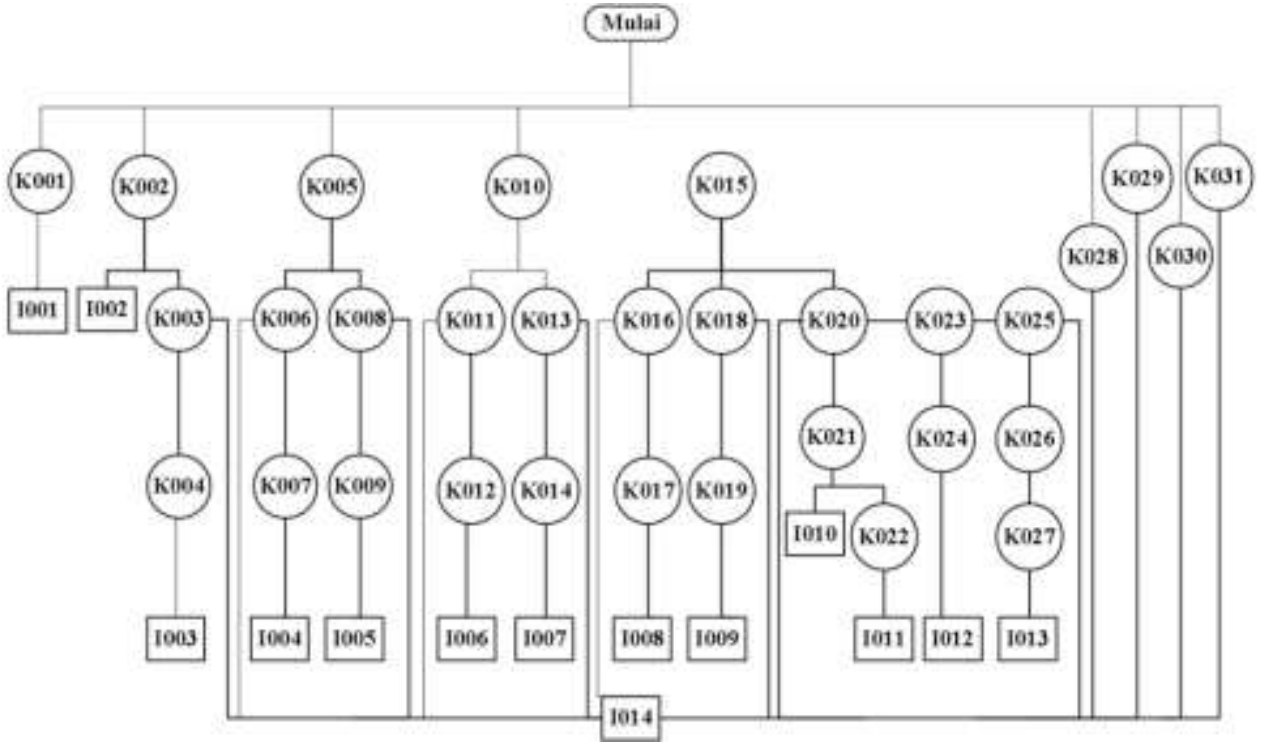

Gambar 2. Pohon Keputusan

\subsection{Pembuatan Aplikasi Remainder Imunisasi Pada Sistem Informasi Posyandu}

\section{A. Analisis kebutuhan}

Hasil mendeteksi permasalahan yang dihadapi oleh bidan dan kader Posyandu, maka dibuatkanlah analisa kebutuhan berupa solusi atas permasalahan yang dihadapi, berupa remainder imunisasi anak pada Sistem Informasi Posyandu. Alur prosedur atas solusi dari permasalahan yang dihadapi bidan dan kader Posyandu dituangkan kedalam alur sistem yang akan dikembangkan.

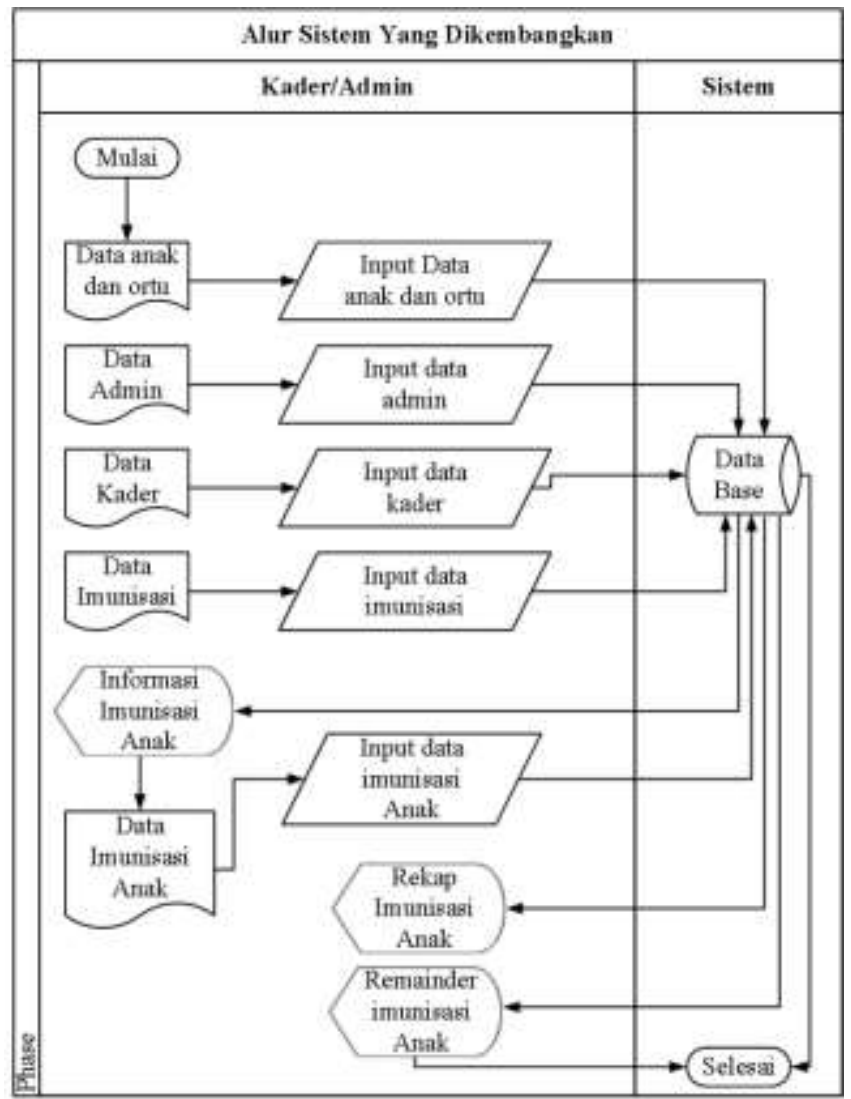

Gambar 3. Prosedur Sistem Yang Akan Dikembangkan 
Penjelasan alur sistem yang akan dikembangkan :

1. Kader atau admin menginputkan data anak dan orang tua

2. Kader atau admin menginputkan data admin dan kader

3. Kader atau admin menginputkan data imunisasi rutin anak

4. Kader atau admin melihat informasi imunisasi rutin anak

5. Kader atau admin menginputkan data imunisasi rutin anak

6. Kader atau admin melihat rekap dan remainder imunisasi anak

\section{B. Perancangan Sistem}

Perancangan sistem remainder imunisasi diimplementasikan melalui use case dan class diagram.

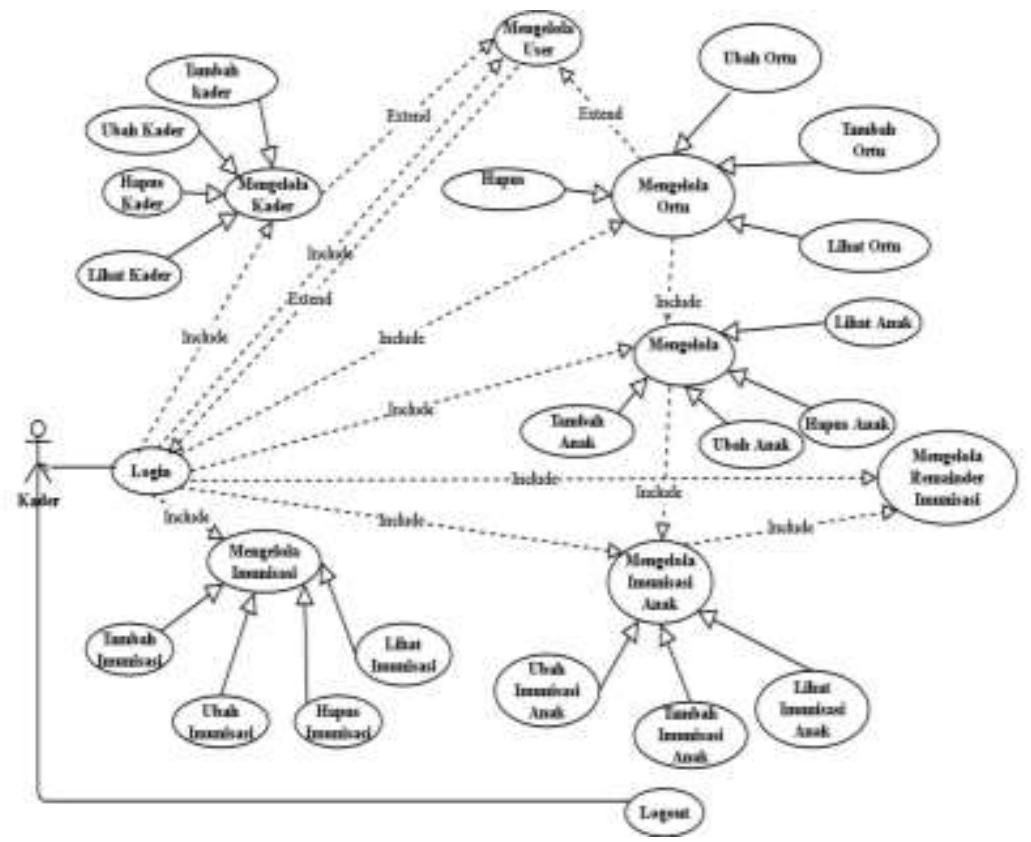

Gambar 4. Use Case Diagram Remainder Imunisasi Anak

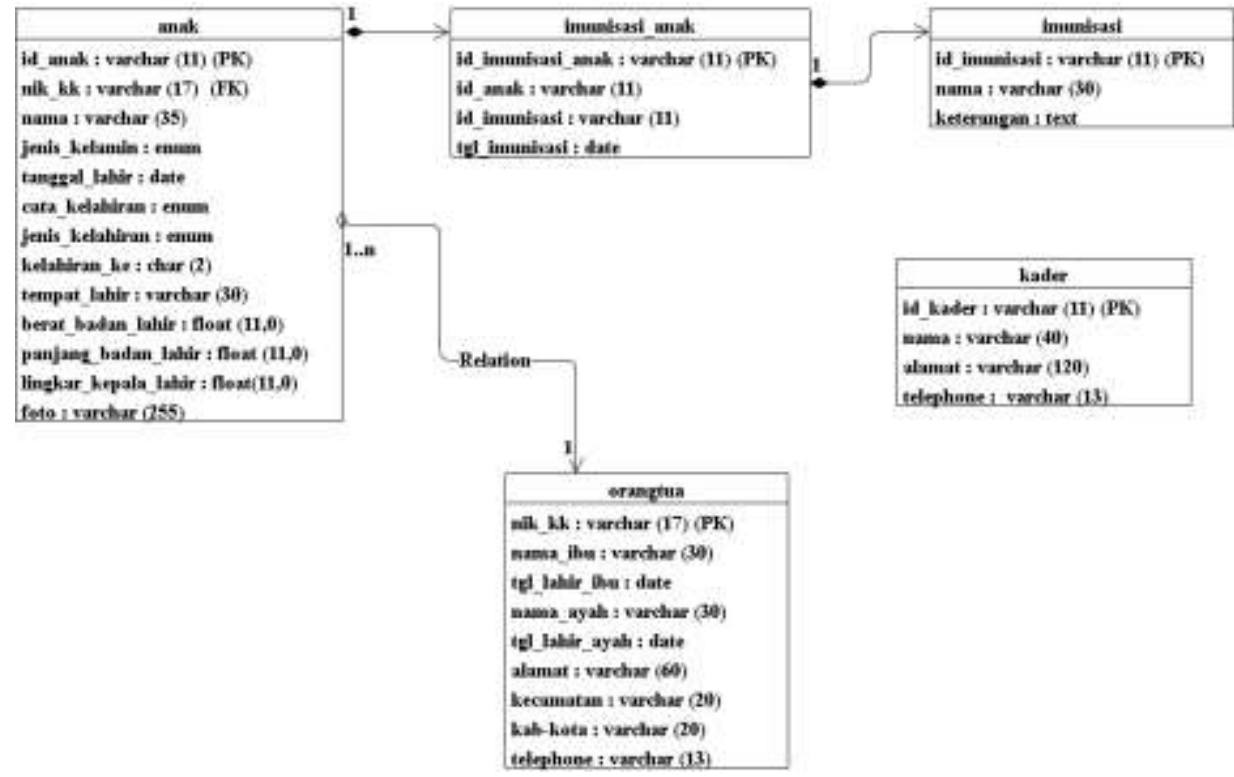

Gambar 5. Class Diagram Remainder Imunisasi Anak 


\section{Implementasi}

Hasil Remainder imunisasi bayi dan balita berbasiskan website memiliki beberapa menu sesuai yang dibutuhkan oleh user. Remainder imunisasi bayi dan balita berbasiskan website memiliki halaman login, halaman utama yang terdiri dari menu user atau admin, menu kader, menu orang tua, menu anak, menu imunisasi, menu imunisasi anak, dan menu list remainder imunisasi anak.

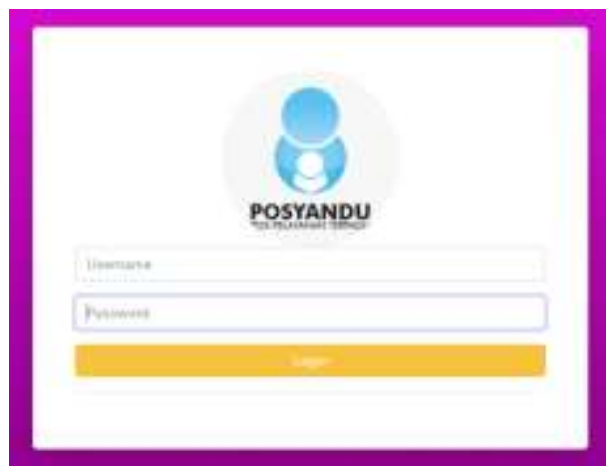

Gambar 6. Halaman Login

Sistem remainder imunisasi ini terdapat 2 bagian yaitu bagian menu sidebar dan konten. Pada bagian menu sidebar terdapat 6 menu yang dapat dipilih yaitu data kader, data orangtua, data imunisasi, data anak, imunisasi anak dan reminder imunisasi. Pada saat menu dipilih maka konten akan berubah-ubah sesuai dengan menu yang dipilih dan bagian menu dapat di kecilkan agar bagian konten terlihat lebih lebar dengan cara klik tombol panah kearah kanan tersebut maka tampilan menu sidebar akan berubah seperti tampilan di sebelah kanan.

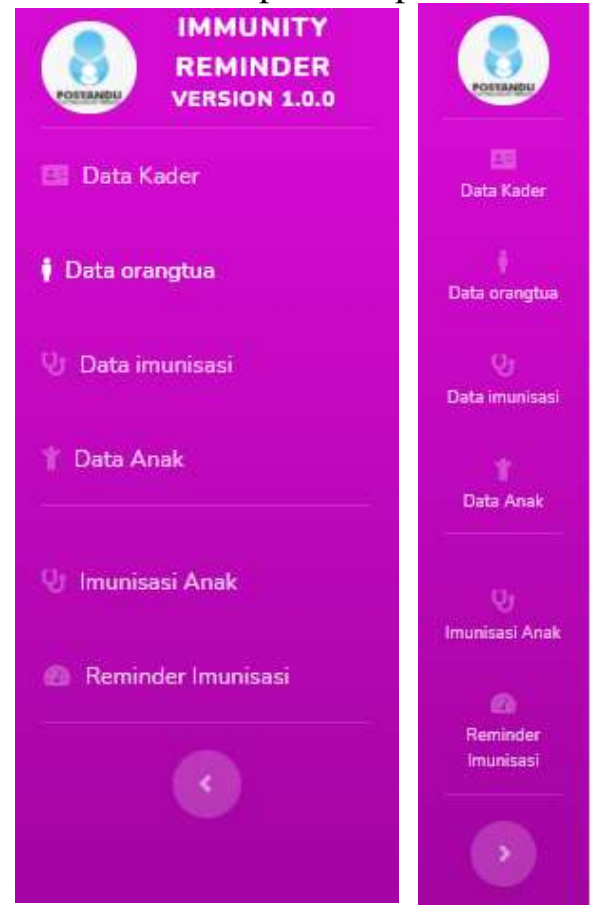

Gambar 7. Menu Sidebar dan Konten pada halaman Utama

Halaman menu data kader untuk melakukan penambahan data kader baru, mengupdate data kader dan menghapus data kader. Halaman menu data orangtua untuk melakukan penambahan data orangtua, mengupdate data orangtua dan menghapus data orangtua. 

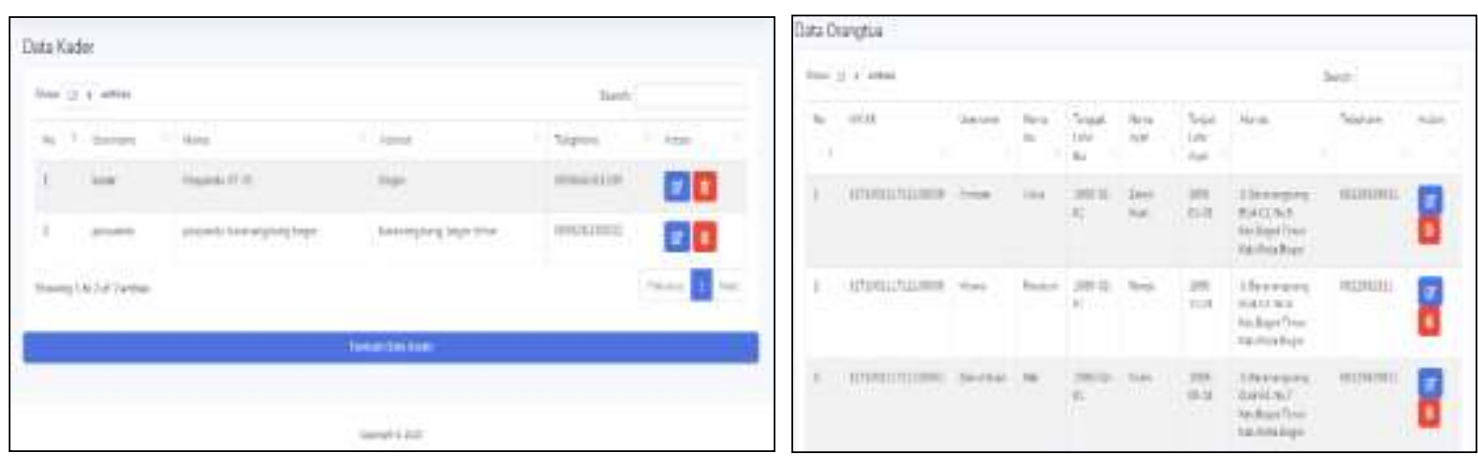

Gambar 8. Halaman Menu Data Kader dan Halaman Menu Data Orang Tua

Halaman menu data imunisasi untuk melakukan penambahan data imunisasi, mengupdate data imunisasi dan menghapus data imunisasi. Halaman mengelola data anak untuk melakukan penambahan data anak, mengupdate data anak dan menghapus data anak.
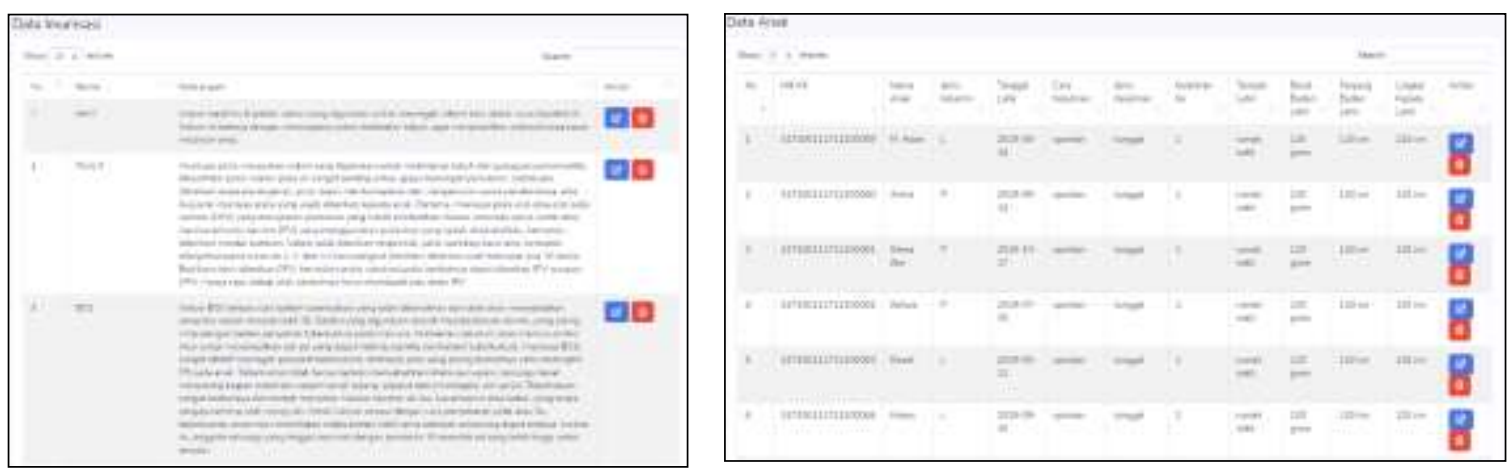

Gambar 9. Halaman Menu Data Imunisasi dan Halaman Menu Data Anak

Halaman Menu reminder imunisasi terdapat informasi nama anak dan imunisasi yang harus diberikan. Imunisasi akan muncul otomatis sesuai dengan jadwal imunisasi anak.

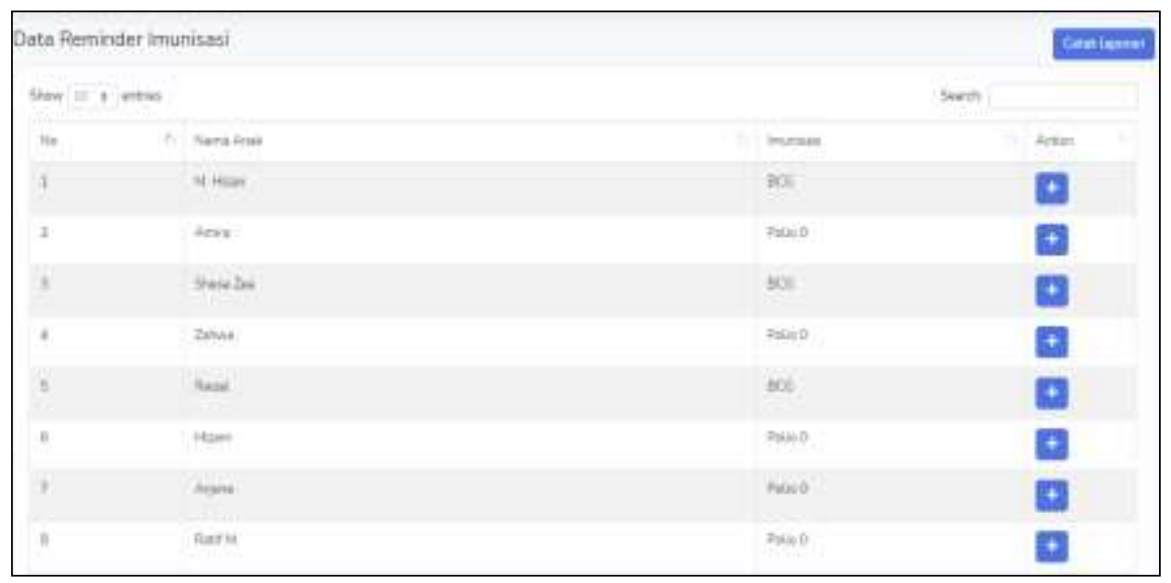

Gambar 10. Halaman Menu Remainder Imunisasi Anak

\section{Uji coba}

Uji coba dilakukan sesuai dengan skenario dokumentasi pengujian yang berlandaskan pada teknik blackbox testing. Berdasarkan Hasil pengujian fungsional dari Sistem Informasi Posyandu, mulai dari menu login, menu pengisian data user dan kader, menu data orang tua dan anak, menu imunisasi, menu imunisasi anak, dan menu remainder imunisasi anak, semua berfungsi dengan baik. Remainder imunisasi muncul secara otomatis tanpa menginputkan secara manual tanggal jadwal imunisasi rutin anak. 
Tabel 4. Hasil Uji coba BlackBox

\begin{tabular}{lll}
\multicolumn{1}{c}{ Menu } & \multicolumn{1}{c}{ Proses } & Hasil \\
\hline Login & Verivikasi dan validasi username dan password & Berfungsi \\
\hline Dashboard & Menampilkan grafik imunisasi anak & Berfungsi \\
\hline User & Tampil, tambah, ubah dan hapus data user (Admin). & Berfungsi \\
\hline Kader & Tampil, tambah, ubah dan hapus data kader & Berfungsi \\
\hline Imunisasi & Tampil, tambah, ubah dan hapus data imunisasi & Berfungsi \\
\hline Orang tua & Tampil, tambah, ubah dan hapus data imunisasi & Berfungsi \\
\hline Anak & Tampil, tambah, ubah dan hapus data anak & Berfungsi \\
\hline Imunisasi anak & Tampil, ubah tanggal imunisasi anak dan cetak laporan & Berfungsi \\
\hline Reminder & Tampil nama dan imunisasi yang harus dilakukan, & Berfungsi \\
Imunisasi & tambah tanggal imunisasi dan cetak laporan & \\
\hline
\end{tabular}

\section{Kesimpulan}

Remainder imunisasi pada Sistem Informasi Posyandu dibuat untuk memantau imunisasi rutin anak. Metode yang digunakan pada remainder imunisasi anak menggunakan dua tahapan yang pertama pelacakan menggunakan metode Forward Chainning dan pencarian penentuan keputusan untuk mengeluarkan notifikasi remainder menggunakan Best First Search. Sistem ini dibuat dengan berbasiskan website, agar mudah diakses dimanapun berada. Sistem diujicoba langsung oleh bidan dan kader di Posyandu Kenanga. Hasil dari ujicoba menyatakan bahwa sistem sudah berhasil memunculkan notifikasi remainder imunisasi setiap anak pada jadwal Posyandu berlangsung sesuai dengan rule imunisasi yang ditetapkan oleh pemerintah. Pembuatan remainder ini sangat membantu bidan dan kader posyandu dalam memantau imunisasi anak khususnya pada saat pandemi COVID 19. Sehingga seluruh anak mendapatkan imunisasi rutin dengan tepat waktu tanpa orang tua khawatir akan terpapar virus COVID 19, karena kader dan bidan akan berkeliling atau membuatkan jadwal khusus untuk anak yang harus diimunisasi sesuai jadwalnya. Agar lebih efektif sistem ini dapat ditambahkan dengan pengiriman informasi jadwal posyandu melalui media whatsapp, penambahan fitur lokasi anak yang diimunisasi menggunakan fasilitas google maps, dan juga klustering lokasi wilayah sesuai dengan status kelengkapan imunisasi.

\section{Daftar Pustaka}

[1] D. Handayani, D. R. Hadi, F. Isbaniah, E. Burhan, dan H. Agustin, "Penyakit Virus Corona 2019," J Respir Indo, Vol. 40, No. 2, April 2020.

[2 ] N. S. Saputri, M. D. Anbarani, N. Toyamah, A. Yumna, "Dampak Pandemi Covid-19 Pada Layanan Gizi Dan Kesehatan Ibu Dan Anak (Kia): Studi Kasus Di Lima Wilayah Di Indonesia,"Catatan Penelitian Smeru No. 5, 2020.

[3] Kementerian Kesehatan RI. Profil Kesehatan Republik Indonesia Tahun 2017. 2018. $107-108 \mathrm{p}$.

[4] Yana Adharani, Popy Meilina," Penjadwalan Imunisasi Anak Usia 0-18 Tahun Menggunakan Metode Forward Chaining", Seminar Nasional TEKNOKA ke -2, Vol.2, 2017

[ 5 ] Surat Edaran Dirjen P2P Nomor SR.02.06/4/1332/2020 tanggal 24 Maret 2020 tentang Pelayanan Imunisasi Pada Anak selama masa Pandemi Corona Virus Disease 2019.

[ 6] Permenkes RI No. 12 Tahun 2017 Tentang Penyelenggaraan Imunisasi

[ 7 ] Petunjuk Teknis Pelayanan Imunisasi pada Masa Pandemi COVID-19, Mei 2020

[ 8 ] Achmad Tasyrif Havaso, Mulyadi, Eddy Suratno," Aplikasi Pengingat Jadwal Imunisasi pada Puskesmas Kebun Handil Kota Jambi Berbasis Android", Journal of Computer and Information Technology, Vol. 2, No. 2, February 2019, Pages 60-65 
[9] Nur Amanah, Ahmad Khambali, Edy Subowo," Sistem Informasi Pengingat Jadwal Imunisasi Pada Puskesmas Karanganyar, Berbasis Web dan Android”, Surya Informatika, Vol.9, No.1, November 2020.

[10] R. R. Fanny, N. A. Hasibuan, and E. Buulolo, "Perancangan Sistem Pakar Diagnosa Penyakit Asidosis Tubulus Renalis Menggunakan Metode Certainty Factor Dengan Penulusuran Forward Chaining," MEDIA Inform. BUDIDARMA, vol. 1, no. 1, Februari 2017.

[11] Hartono Gunardi, Cissy B. Kartasasmita, Sri Rezeki S. Hadinegoro, Hindra Irawan Satari, Soedjatmiko, Hanifah Oswari, Hardiono D. Pusponegoro, Jose R. Batubara, Arwin AP. Akib, Badriul Hegar, Piprim B. Yanuarso, Toto Wisnu Hendrarto, "Jadwal imunisasi anak usia 0 - 18 tahun rekomendasi IDAI 2017", Sari Pediatri, Vol. 18, No. 5, Februari 2017.

[12] Redo Abeputra Sihombing, "Sistem Pakar Untuk Mendiagnosa Gangguan Pada Sistem Hepatobiliaris Berbasis Android Mobile", Jurnal String Vol. 3 No.1 Agustus 2018.

[13] Ibnu Akil, "Analisa Efektifitas Metode Forward Chaining Dan Backward Chaining Pada Sistem Pakar", Jurnal Pilar Nusa Mandiri, Vol 13, No.1, Maret 2017.

[14] Herman Susilo,"Sistem Pakar Metode Forward Chaining dan Certainty Factor Untuk Mengidentifikasi Pernyakit Pertusis Pada Anak", Rang Teknik Journal Vol.1, No.2, Juni 2018

[15] Asosiasi Penyelenggara Jasa Internet Indonesia, 2020

[16] Kirman, Andika Saputra, Jacky Sukmana," Sistem Pakar Untuk Mendiagnosis Penyakit Lambung Dan Penanganannya Menggunakan Metode Dempster Shafer", Jurnal Pseudocode, Volume VI Nomor 1, Februari 2019.

[17] M. Indah, S. V. Dewi, "Rancangan Sistem Pakar Mendiagnosa Penyakit Lambung Menggunakan Metode Forward Chaining," Journal of Informatics and Computer Science Vol. 4 No. 2, Oktober 2018.

[18] Husni Angriani, Yeni Saharaeni, "Implementasi Algoritma Best First Search Dalam Sistem Pakar Pertolongan Pertama Pada Bayi Dan Anak", Jurnal Teknologi Informasi dan Komunikasi, Vol. 10, No. 2, Desember $2020: 116$ - 122

[19] C. Tristianto," Penggunaan Metode Waterfall Untuk Pengembangan Sistem Monitoring Dan Evaluasi Pembangunan Pedesaan," Jurnal Teknologi Informasi Esit Vol. Xii No. 01 April 2018

[20] Dede Wira Trise Putra, Rahmi Andriani, "Unified Modelling Language (UML) dalam Perancangan Sistem Informasi Permohonan Pembayaran Restitusi SPPD", Jurnal TEKNOIF, Vol. 7 No. 1 April 2019

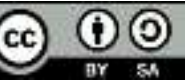

Digital Zone: Jurnal Teknologi Informasi dan Komunikasi is licensed under a Creative Commons Attribution International (CC BY-SA 4.0) 